\title{
ATTITUDE OF THE FACULTY MEMBERS TOWARDS INFORMATION AND COMMUNICATION TECHNOLOGY (ICT) IN STATE
}

AGRICULTURAL UNIVERSITIES

P. V. SATHYA GOPAL, K. SHIREESHA \& N. P. ESWARA REDDY

ICAR Extramural Research Project, Department of Agricultural Extension

S.V.Agricultural College, Acharya N.G. Ranga Agricultural University, Tirupati, India

The Information and Communication Technology (ICT) is a very broad term, focusing on improving the quality, quantity and speed of information reach the students in an educational system. ICT is becoming the basic building blocks of modern society. Many countries now regard understanding ICT and mastering the basic skills and concepts of ICT as part of the core of education, alongside reading, writing and numeracy. With ICT, teachers are able to create their own material and thus have more control over the material used in the classroom than they have had in the past. ICT in agricultural education also has paramount importance to bring reality to the teaching learning process. Ample numbers of ICT tools were also being designed and regularly refined to suit to the teaching learning process in agricultural education. Several research studies were taken up in the host institution on ICT training needs of the faculty members, and the extent of utilization of available ICT tools. But the attitude of faculty members towards ICT was not stressed much in the past research studies which are the most vital component influence the application of ICT. Hence the present study was taken up under the ICAR extramural research project during the year 2016-17 with the objective of analyzing the attitude of the faculty members towards ICT and also the factors influencing the attitude of the faculty members towards ICT utilization in Agricultural education. The study revealed that more than one third of the faculty members had a neutral attitude towards ICT utilization followed by moderately favorable attitude. Just about one fourth of them had shown moderate to highly unfavorable attitude. On the other side, the highlyfavorablee attitude towards ICT utilization was noticed by nearly 13.13 per cent of the faculty members. The study revealed that Global knowledge sharing, Speedy delivery of information, Effective presentation, updating knowledge and exploring unimaginable information were found to be more significant concepts ranked first, second, third, fourth and fifth with $\mathrm{Z}$ values 0.864 , $0.832,0.764,0.713$ and 0.706 respectively and these five concepts contributed more for having a positive attitude towards ICT utilization by the faculty members in State Agricultural Universities. It was observed that the process factors like awareness, possession of knowledge, application proficiency and extent of ICT utilization has shown a positive significant relationship with the attitude of the faculty members in State Agricultural Universities.

KEYWORDS: ICT, Attitude, Faculty Members, Utilization \& State Agricultural Universities
\end{abstract}

Received: Nov 20, 2017; Accepted: Dec 11, 2017; Published: Mar 01, 2018; Paper Id.: IJESRAPR20183

\section{INTRODUCTION}

The Information and Communication Technology (ICT) is a very broad term, focusing on improving the quality, quantity and speed of information reach the students in an educational system. ICT has become, within a very short time, one of the basic building blocks of modern society. Many countries now regard understanding 
ICT and mastering the basic skills and concepts of ICT as part of the core of education, alongside reading, writing and numeracy. With ICT, teachers are able to create their own material and thus have more control over the material used in the classroom than they have had in the past. ICT offers an excellent opportunity for improved coordination across the agricultural nexus, bridging the information gap, sharing information and creation of knowledge. Tinio (2002), states the potentials of ICTs in increasing access and improving relevance and quality of education in developing countries. In spite of committed efforts, the utilization of ICT tools in agricultural education is still not reaching the expectations of the stakeholders.

Jeevan and Nair (2004) reported that the problems faced in ICT adoption included inadequacy of funds, shortage of IT skilled manpower, difficulties in periodic up-gradation of infrastructural facilities, frequent change and advancement of technology, high hardware and software costs, insufficient training of professionals and absence of hands-on training. Walmiki and Ramakrishnegowda (2009) revealed that most of the universities lack sufficient hardware and software facilities, and internet with the required bandwidth to exploit the benefits of digital information environment. Kannappanavar and Vijayakumar, (2001) observed that, though the agricultural university is having hardware and software facilities to some extent, the results are not reaching the clientele. It recommends that the faculty should be trained on IT application. Most teachers do not make use of the potential of ICT to contribute to the quality of learning environments, although they value this potential quite significantly (Smeetset al., 2005). Harris (2002) concluded that the benefits of ICT will be gained “... when confident teachers are willing to explore new opportunities for changing their classroom practices by using ICT. Sampath Kumar and Biradar (2010) reported that, even though faculty members have shown a positive attitude towards the use of ICT applications and automation, a majority expressed the need for appropriate training to make use of ICT tools. To explore such gaps and to bring a modest approach to the faculty members to learn and efficiently utilize the ICT in their teaching endeavor, the present study was taken up under the ICAR extramural research project during the year 2016-17with the objective of analyzing the attitude of the faculty members towards ICT and also the factors influencing the attitude of the faculty members towards ICT utilization in Agricultural education.

\section{MATERIALS AND METHODS}

The study was conducted Southern India covering Andhra Pradesh, Telangana, Karnataka and Tamil Nadu states by using Ex-post facto research design. Two State Agricultural Universities (SAUs) from each of the selected four states were selected and thus making a total of eight SAUs. Two Colleges from each SAU were selected and thus making a total of sixteen colleges. Thirty faculty members were selected from each of the selected college thus makes a total of four hundred and eighty (480) faculty members as respondents.

Attitude of faculty members towards ICT utilization was measured with the help of five point scale developed for the study. The final scale selected with 18 statements was administered to the 480 sampled faculty members. They were requested to give responses to each statement in terms of their own degree of agreement or disagreement on a five point continuum. Each statement of scale was provided with five point continuum viz., strongly agree (SA), agree (A), undecided (UD), disagree (DA), strongly disagree (SDA) with scores of 5, 4, 3, 2 and 1 respectively for positive statements and 1,2,3,4 and 5 for negative statements. The total score of the respondent on the scale was obtained by summing up the scores of all the statements in the scale. The possible minimum and maximum score was 18and 90. The respondents were grouped into the following five categories based on the scores obtained by each of them duly following mean and standard deviation. 


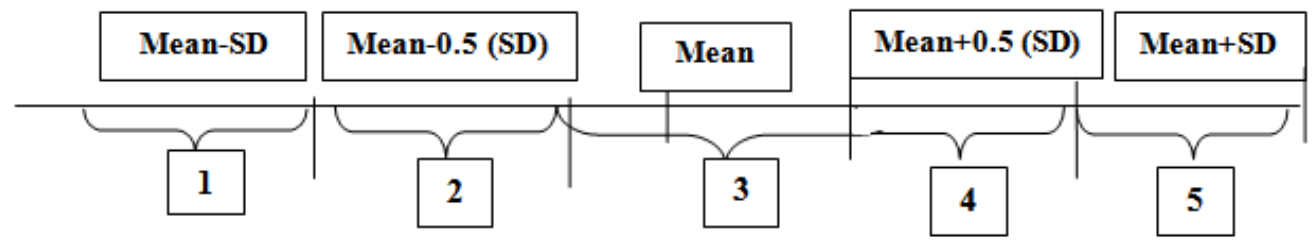

\begin{tabular}{|c|l|l|}
\hline S. No. & \multicolumn{1}{|c|}{ Category } & \multicolumn{1}{c|}{ Score Range } \\
\hline 1. & Highly unfavorable & Below Mean-SD \\
\hline 2. & Moderately unfavorable & Between Mean-SD and Mean-0.5 (SD) \\
\hline 3. & Neutral & Between Mean-0.5 (SD) and Mean+0.5(SD) \\
\hline 4. & Moderately favorable & Between Mean+0.5(SD) and Mean+SD \\
\hline 5. & Highly favorable & Above Mean+SD \\
\hline
\end{tabular}

Standard Normal Deviates (Z) test was used to critically analyze the different statements in the attitude scale for prioritizing the important areas influencing the attitude of the faculty members towards ICT utilization. In order to study the nature of the relationship between the attitude and process factors under ICT utilization by the faculty members,Chi square test followed by Binary logistic regression was performed to find out the correlating factors and to identify the contributing factors for attitude towards ICT utilization by the faculty members of State Agricultural Universities. This has been done by following Binary Logistic regression steps using SPSS 16.0 version.

\section{RESULTS AND DISCUSSIONS}

The results of the study were presented under three subheads viz., the attitude of the faculty members towards ICT utilization, critical analysis of different statements in the attitude scale and also the factors correlating and contributing factors for the attitude of the faculty members towards ICT utilization but the faculty members.

\section{Attitude of the Faculty Members towards ICT Utilization}

From Table 1, it is evident that, more than one third $(38.96 \%)$ of the faculty members had a neutral attitude towards ICT utilization followed by 19.38 per cent of them had moderately favorable attitude. About 14.38 and 14.17 per cent of them had shown moderately and highly unfavorable attitude respectively. On the other side highly favorable attitude towards ICT utilization was noticed by nearly 13.13 per cent of the faculty members.

Table 1: Distribution of Faculty Members According to their Attitude

\begin{tabular}{|c|c|c|c|}
\hline S. No. & Attitude & $\mathbf{n}$ & $\%$ \\
\hline 1. & Highly unfavorable & 68 & 14.17 \\
\hline 2. & Moderately unfavorable & 69 & 14.38 \\
\hline 3. & Neutral & 187 & 38.96 \\
\hline 4. & Moderately favorable & 93 & 19.38 \\
\hline \multirow[t]{2}{*}{5.} & Highly favorable & 63 & 13.13 \\
\hline & Total & 480 & 100 \\
\hline \multicolumn{2}{|c|}{ Mean $=68.21$} & & \\
\hline
\end{tabular}

\section{Critical Analysis of Different Statements in the Attitude Scale}

Based on the data analysis, critical concepts of attitude statements were analyzed and were depicted in table 2 . It is clear that the 'Global knowledge sharing', 'Speedy delivery of information', 'Effective presentation, updating knowledge' and 'exploring unimaginable information' were found to be more significant concepts ranked first, second, third, fourth and fifth with $\mathrm{Z}$ values $0.864,0.832,0.764,0.713$ and 0.706 respectively. 
Table 2: Critical Analysis of Attitude of Faculty Members towards ICT Utilization

\begin{tabular}{|c|c|c|c|c|c|c|}
\hline $\begin{array}{l}\text { S. } \\
\text { No }\end{array}$ & Statement & Critical concept & $\begin{array}{c}X \\
\text { value }\end{array}$ & S D & \begin{tabular}{c|c}
$\mathrm{Z}$ \\
Value
\end{tabular} & Rank \\
\hline 1 & $\begin{array}{l}\text { ICT is an effective means for sharing of } \\
\text { global knowledge }\end{array}$ & Global knowledge sharing & 4.335 & 0.631 & 0.864 & I \\
\hline 2 & $\begin{array}{l}\text { ICT utilization helps in the speedy } \\
\text { delivery of information }\end{array}$ & Speedy delivery of information & 4.333 & 0.654 & 0.832 & II \\
\hline 3 & $\begin{array}{l}\text { Presentation of topics can be effective } \\
\text { through ICT utilization }\end{array}$ & Effective presentation & 4.344 & 0.726 & 0.764 & III \\
\hline 4 & $\begin{array}{l}\text { ICT utilization updates the knowledge of } \\
\text { a teacher }\end{array}$ & Updating knowledge & 4.277 & 0.684 & 0.713 & IV \\
\hline 5 & $\begin{array}{l}\text { One can explore unimaginable } \\
\text { information through ICT utilization }\end{array}$ & $\begin{array}{l}\text { Exploring unimaginable } \\
\text { information }\end{array}$ & 4.296 & 0.717 & 0.706 & V \\
\hline 6 & I don't have interest to use ICTs & Interest in ICTs & 4.263 & 0.878 & 0.539 & VI \\
\hline 7 & $\begin{array}{l}\text { ICT utilization widens the vision of a } \\
\text { teacher }\end{array}$ & Widens vision & 4.150 & 0.698 & 0.517 & VII \\
\hline 8 & $\begin{array}{l}\text { Monotony of work can be reduced by } \\
\text { using ICT }\end{array}$ & Reducing Monotony & 4.181 & 0.806 & 0.486 & VIII \\
\hline 9 & $\begin{array}{l}\text { ICT utilization is the stepping stone for } \\
\text { the global development }\end{array}$ & Global development & 4.100 & 0.809 & 0.384 & IX \\
\hline 10 & ICT utilization saves the time of a teacher & Time Saving & 4.010 & 0.787 & 0.280 & $\mathrm{X}$ \\
\hline 11 & $\begin{array}{l}\text { ICT utilization is imperative for the } \\
\text { growth of education }\end{array}$ & Vital for educational growth & 3.994 & 0.878 & 0.233 & XI \\
\hline 12 & $\begin{array}{l}\text { Utilization of ICT is very difficult to } \\
\text { understand }\end{array}$ & Difficulty in understanding & 3.783 & 0.911 & -0.007 & XII \\
\hline 13 & Black board is enough for teaching & Black board is enough & 3.569 & 1.048 & -0.211 & XIII \\
\hline 14 & $\begin{array}{l}\text { Most of my time is wasted in browsing of } \\
\text { information }\end{array}$ & Time wasted & 3.525 & 1.071 & -0.247 & XIV \\
\hline 15 & $\begin{array}{l}\text { ICT utilization will hamper the } \\
\text { practicality of Agricultural education }\end{array}$ & Hamper the practicality & 3.315 & 1.119 & -0.425 & XV \\
\hline 16 & $\begin{array}{l}\text { ICT utilization is surpassing the gravity } \\
\text { of the information }\end{array}$ & $\begin{array}{l}\text { Surpass gravity of the } \\
\text { information }\end{array}$ & 2.819 & 0.947 & -1.026 & XVI \\
\hline 17 & $\begin{array}{l}\text { Self-thinking is ignored due to high } \\
\text { dependence on ICT }\end{array}$ & $\begin{array}{l}\text { Ignore } \\
\text { Self-thinking }\end{array}$ & 2.585 & 1.133 & -1.063 & XVII \\
\hline 18 & $\begin{array}{l}\text { More scope for plagiarism through ICT } \\
\text { utilization }\end{array}$ & Plagiarism & 2.333 & 1.045 & -1.394 & XVIII \\
\hline
\end{tabular}

These five concepts contributed more for having a positive attitude towards ICT utilization by the faculty members in State Agricultural Universities. The faculty members might be utilizing ICTs mostly for getting information which enriches their knowledge in the concerned subject. They also might have experienced quick gathering of information with ICTs as compared to the traditional modes. On the other side, they might be effectively utilized ICTs primarily for their classroom presentations and enjoying the satisfaction through ICTs. Frequent browsing might be contributing for their knowledge update required for handling the teaching and research activities. Sometimes they also might have received the incredible information to support their present level of understanding which may broaden their intellectual capacity towards proficiency in teaching

'Interest on ICTs', 'Widens vision', 'Reducing Monotony, 'Global development', 'Time saving' and 'Vital for educational growth' were found to be other concepts ranked sixth, seventh, eighth, ninth, tenth and eleventh with $\mathrm{Z}$ values $0.539,0.517,0.486,0.384,0.280$ and 0.233 respectively. 
These six concepts also might have influenced for having a positive attitude towards ICT utilization by the faculty members in State Agricultural Universities. Lack of interest among the poor ICT users and having interest among the ICT users also played major role in ICT utilization among the faculty members. The ICTs also might be showing the ways and means for realizing their dreams for their academic excellence. Further, the ICTs might be alienating the repeated work in academics, which made the faculty member free from such monotonous activities. They also might be in thinking that ICTs is going to the trend setters for global development due to their cutting edge technologies. The faculty might have experienced the conservation of precious time, which is the need of the hour. They also might have projected the importance of ICTs for the future growth of agricultural education so as to meet the changing demands of agriculture.

'Difficulty in understanding', 'Black board is enough', 'Time wasted', 'Hamper the practicality', 'Surpass gravity of information', 'Ignore Self-thinking' and 'Plagiarism' were found to be the concepts ranked twelfth to eighteenth with $\mathrm{Z}$ values $-0.007,-0.211,-0.247,-0.425,-1.026,-1.063$ and -1.394 respectively. These six concepts also might have influenced for having a positive attitude towards ICT utilization by the faculty members in State Agricultural Universities. Some of them had the problem of understanding ICTs due to lack of proper guidance and continues persuasion in learning of ICTs. Even though majority felt black board never be replaced with any ICT but they might have known the need for its use for future education. Sometimes, the ICTs might be wasting the time of a faculty due to unwanted information as well as operational maintenance, but the net worth might be towards the positive side. Heavy dependence on ICTs sometimes may lead to avoiding the practicality and rely upon virtual to attract the students. Further, there might be every possibility of surpassing the gravity of information as well as self-thinking ability of a person. This is also an issue considered by the faculty to use ICTs. No doubt, plagiarism is a threat out of ICTs, but the faculty might have felt that there should be a mechanism to curtail plagiarism than discouraging ICTs. As a whole, the analysis of eighteen concepts of attitude towards ICT utilization has revealed the vital areas to be focused for strengthening ICT utilization in agricultural education.

\section{Correlating and Contributing Factors for Attitude of the Faculty Members TowardS ICT Utilization Bt the Faculty Members}

The Pearson's coefficient of correlation values for Awareness (0.100), possession of knowledge (0.134), application proficiency $(0.124)$ and extent of ICT utilization $(0.171)$ were found to be more than ' $r$ ' table value and hence it could be inferred that, there was a positive and significant relationship between awareness, possession of knowledge,application proficiency and extent of ICT utilization by the faculty members.

Table 3: Correlation between Attitude and Process Factors Responsible for Extent of ICT Utilization by the Faculty Members in SAUs

\begin{tabular}{|l|c|c|}
\hline Process Factors & Pearson Correlation & P Value \\
\hline Awareness & $.100(*)$ & 0.029 \\
\hline Accessibility & 0.079 & 0.085 \\
\hline Possession of Knowledge & $0.134(* *)$ & 0.003 \\
\hline Application Proficiency & $0.124(* *)$ & 0.007 \\
\hline Extent of ICT Utilization & $0.171(* *)$ & 0.000 \\
\hline
\end{tabular}

On the other side, Accessibility (0.079) was found to be less than r' table value and hence it could be inferred that, there was a nonsignificant relationship between accessibility and attitude towards ICT utilization by the faculty members. The faculty members might be aware of the existence of different ICT tools and also they might eager to learn knowledge and skills to utilize the ICTs in their academic environment, But the accessibility could not be contributing for variation in attitude as the faculty members felt the need of the ICTs for stregthening agricultural education. 


\section{CONCLUSIONS}

The majority of the faculty members were having a favorable attitude towards ICT utilization. This is one of the driving force to enhance the ICT utilization among the faculty members. The concepts like 'Difficulty in understanding', 'Black board is enough', 'Time wasted', 'Hamper the practicality', 'Surpass gravity of information', 'Ignore Self-thinking' and 'Plagiarism' which were developing a negative attitude towards ICT utilization has to be focused more to enhance the ICT utilization among the faculty members. Further the process factors like awareness, possession of knowledge, application proficiency and extent of ICT utilization were the determining factors for attitude ICT utilization. Hence, these factors also be considered while designing the strategies for enhancing the ICT utilization among the faculty members in State Agricultural Universities.

\section{REFERENCES}

1. Jeevan, V. K., \& Nair, S. S. (2004). Information technology adoption in libraries of Kerala : A survey of selected libraries in Thiruvananthapuram. Annals of library and information studies , 51 (4), 137-144.

2. Kannappanavar, B. U., \&Vijayakumar, M. (2001). Use of IT in university of agricultural science libraries of Karnataka: A Comparative Study. Desidoc bulletin of information technology, 21 (1), 21-26.

3. Kumar, B. T.S., \&Biradar, B. S. (2010). Use of ICT in College Libraries in Karnataka, India: a Survey. Program: Electronic Library and Information Systems , 44 (3), 271 - 282.

4. Afroze Nazneen \& Pretty Bhalla, A Study of Organizational Role Stress and Organizational Commitment among the Faculty Members of Public and Private Universities, International Journal of Human Resource Management and Research (IJHRMR), Volume 4, Issue 3, June - July 2014, pp. 69-76

5. Smeets, E., Mooij, T., Bamps, H., Bartolom, A., Lowyck, J., Redmond, D., \& Steffens, K. (1999). The Impact of Information and Communication Technology on the Teacher. Nijmegen, the Netherlands: University of Nijmegen, ITS.

6. Tinio, V.L. (2002). ICT in Education: UN Development Programme. (Retrieved from http:www.eprmers.org on December 2009)

7. Walmiki, R. H., \&Ramakrishnegowda, C. K. (2009). ICT infrastructure in university libraries in Karnataka. Annals of Library and information studies, 56, 236-241. 